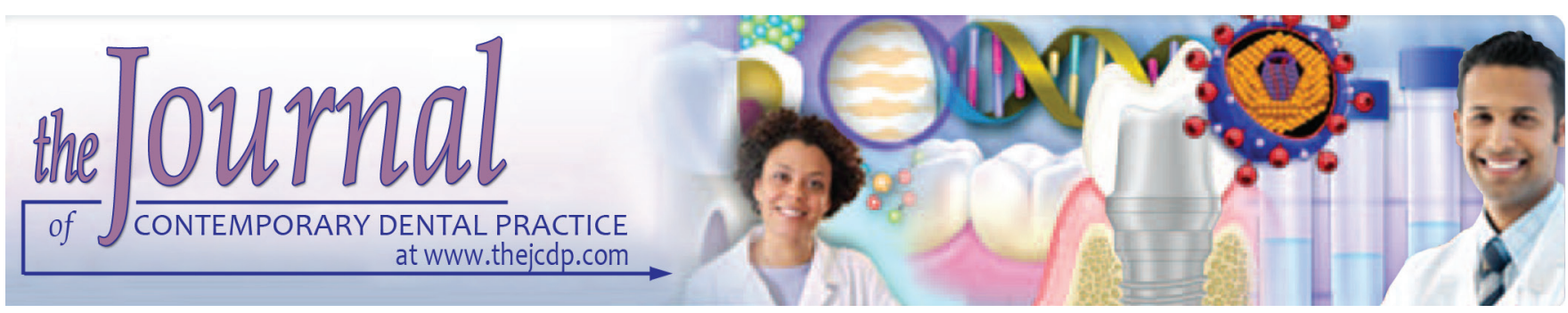

\title{
Impact of Various Irrigating Agents on Root Fracture: An in vitro Study
}

\author{
${ }^{1}$ Sukriti Tiwari, ${ }^{2}$ Pradnya Nikhade, ${ }^{3}$ Manoj Chandak, ${ }^{4} \mathrm{C}$ Sudarshan, ${ }^{5}$ Priyadarshini Shetty, ${ }^{6}$ Naveen K Gupta
}

\begin{abstract}
Introduction: Irrigating solutions are used for cleaning and removing dentinal debris, and the other remains from pulpal space during biomechanical preparation. Therefore, we evaluated the impact of various irrigating agents on root fracture at 5-minute time exposure.
\end{abstract}

Materials and methods: We sectioned 60 permanent maxillary premolars with fully formed root structures transversely maintaining the root length of approximately $14 \mathrm{~mm}$. Five study groups were made comprising ethylenediaminetetraacetic acid (EDTA), cetrimide, citric acid, and so on as various irrigating agents. A universal force test machine was used to calculate the force which was enough to fracture each root. Analysis of variance (ANOVA) test was used to access the level of significance.

Results: About $10 \%$ citric acid solution as an irrigating agent showed minimal fracture opposing results, whereas 10\% EDTA solution showed the maximum fracture resistance of root portion.

Clinical significance: Selection of suitable EDTA concentration that has minimal adverse effect on the mechanical properties of the tooth is very important for the successful management of tooth fracture.

Conclusion: About 10\% EDTA provided the highest fracture resistance, necessitating the use of irrigating solution in root canal therapy (RCT). Further research with higher and different study groups is required to search for more efficient irrigating solution to improve the outcome of RCT.

Keywords: Ethylenediaminetetraacetic acid, Fracture, Irrigating agents.

\footnotetext{
1-3Department of Conservative Dentistry and Endodontics, Sharad Pawar Dental College and Hospital, Wardha, Maharashtra, India

${ }^{4}$ Department of Conservative Dentistry and Endodontics, Pandit Deendayal Upadhyay Dental College, Solapur, Maharashtra, India ${ }^{5}$ Department of Conservative Dentistry, Dr. D. Y. Patil Dental College \& Hospital, Pune, Maharashtra, India

${ }^{6}$ Department of Conservative Dentistry and Endodontics New Horizon Dental College \& Research Institute, Bilaspur Chhattisgarh, India

Corresponding Author: Sukriti Tiwari, Postgraduate Student Department of Conservative Dentistry and Endodontics, Sharad Pawar Dental College and Hospital, Wardha, Maharashtra, India Phone: +919501544877, e-mail: drsukrititiwari@gmail.com
}

How to cite this article: Tiwari $S$, Nikhade $P$, Chandak $M$, Sudarshan C, Shetty P, Gupta NK. Impact of Various Irrigating Agents on Root Fracture: An in vitro Study. J Contemp Dent Pract 2016;17(8):659-662

Source of support: Nil

Conflict of interest: None

\section{INTRODUCTION}

One of the common reasons for the failure of root canal therapy $(\mathrm{RCT})$ is the persistence of infection within the apical part of the canals treated with RCT. The complex anatomical shape of the root canal prohibits complete removal of microorganisms by routine instrumentation procedures. ${ }^{1}$ Irrigation plays a very crucial role in counteracting this problem. Sodium hypochlorite $(\mathrm{NaOCl})$ is the most frequently used irrigating solution, but it also has certain limitations of causing cytotoxicity, corrosion of instruments, and so on. ${ }^{2,3}$ Another commonly used irrigating agent is ethylenediaminetetraacetic acid (EDTA), which dissolves the inorganic component. ${ }^{4}$ Ethylenediaminetetraacetic acid also provides additional advantages, such as helping in RCT procedures, ease of access for root canal armamentarium, and minimal or reduced corroding activities for instruments. In addition, it is also useful in preparing teeth with calcified canals. ${ }^{5}$ It offers numerous additional positive effects acting as an antibacterial agent because of its effectiveness against viable bacteria. Being chemically stable, its longevity is high. ${ }^{5-7}$ Citric acid is also additionally added as an irrigating agent because it completely removes the remaining inorganic components of the root canal materials and smear layer. Also, it decalcifies the carious part of root dentin. ${ }^{7}$ Citric acid has been implicated in previous research works on irrigating effects of different solutions in varying concentrations..$^{8-10}$ Because of weakening of tooth structure due to carious process, the risk of root fracture during instrumentation process is increased. ${ }^{11,12}$ This increases the search for irrigating agents, which has 
a positive effect on increasing the fracture resistance of the tooth undergoing or undergone with RCT procedures. Thus, the aim of the study was to access the impact of different irrigating agents on tooth fracture, root portion at 5 minutes time exposure.

\section{MATERIALS AND METHODS}

The study group included 60 permanent maxillary premolars whose root structures were fully formed. Immediately after extraction, the teeth were cleaned and stored in normal saline at room temperature (according to the Occupational Safety and Health Administration guidelines). Roots of all the specimens were sectioned transversely by maintaining the length of the root to approximately $14 \mathrm{~mm}$. Visual analysis of all the teeth was done to ensure the absence of tooth structural defects, such as cracks, and this was done with the help of fiberoptic light. A standard root canal procedure was initiated on the specimen starting with measuring of the root canal length, which was kept $1 \mathrm{~mm}$ short. Biomechanical preparation was done up to file size no. 15. Sodium hypochlorite with a concentration of approximately $2 \%$ was used as an irrigating agent during the biomechanical procedure. The samples were divided into five experimental groups, with 12 teeth each (Table 1 ).

Universal force testing machine (Fig. 1) was used to calculate the fracture strength by applying fracture test

Table 1: List of groups

\begin{tabular}{|c|c|c|c|}
\hline Sl. no & Groups & $\begin{array}{l}\text { Number of } \\
\text { samples }\end{array}$ & Placement technique \\
\hline 1 & $\mathrm{I}$ & 12 & $10 \mathrm{~mL}$ irrigation with saline \\
\hline 2 & II & 12 & $10 \mathrm{~mL}$ of $10 \%$ EDTA \\
\hline 3 & III & 12 & $\begin{array}{l}10 \mathrm{~mL} \text { of } 15 \% \text { EDTA + cetrimide } \\
0.75 \%\end{array}$ \\
\hline 4 & IV & 12 & $10 \mathrm{~mL}$ of $17 \%$ EDTA \\
\hline 5 & V & 12 & $\begin{array}{l}10 \mathrm{~mL} \text { of citric acid } 10.5 \%+ \\
\text { cetrimide } 0.2 \%+1 \% \text { doxycycline } \\
\text { hyclate + polypropylene glycol }\end{array}$ \\
\hline
\end{tabular}

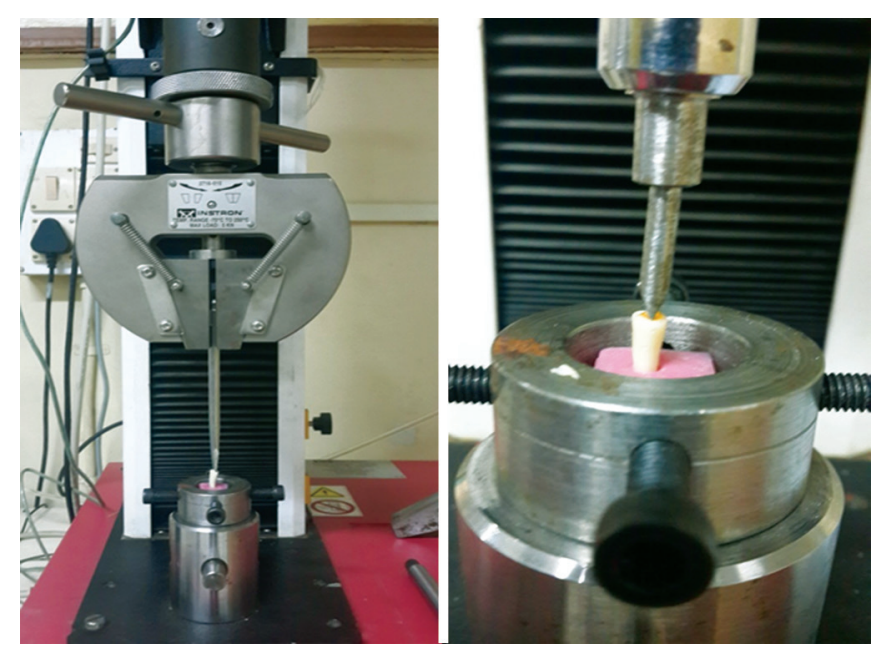

Fig. 1: Samples mounted on universal testing machine on the teeth embedded in their apical-most part along their long axis.

Statistical test used for the analysis of the result was one-way analysis of variance (ANOVA) test.

\section{RESULTS}

One-way ANOVA: The mean maximum compressive load of control group was 612.91 $\pm 8.26,10 \%$ EDTA was $540.08 \pm 9.82,17 \%$ EDTA was 375.83 \pm 31.11 , Largal Ultra was $461.08 \pm 2704$, and citric acid was $326.83 \pm 13.36$. By using one-way ANOVA, a statistically significant variation was found in the maximum compressive load in five groups $(\mathrm{F}=400.52$, $\mathrm{p}=0.000)$.

The fracture resistance values $(\mathrm{N})$ are presented in Table 2 as mean and standard deviation. Statistically significant differences were detected among the groups by using one-way ANOVA ( $\mathrm{p}<0.05)$. The highest mean fracture resistance was obtained from the group treated with $10 \%$ EDTA for 5 minutes. This is about twice more than the weakest mean fracture resistance, which was obtained from the $10 \%$ citric acid 5 minute group. In addition, the fracture resistance of root canal dentin irrigated with 17\% EDTA for 5 minutes was statistically lower compared with positive control (saline water).

\section{DISCUSSION}

During RCT, instrumentation can create a smear layer containing microorganisms, their by-products creating obstacles in the treatment procedure by blocking the dentinal tubules. ${ }^{13,14}$ Therefore, complete removal of this smear layer causes penetration of root canal filling materials and medicaments into the dentinal tubules. ${ }^{13,15}$ The main process that helps to remove this smear layer and other dentinal debris is irrigation. ${ }^{16}$ Various irrigating solutions may cause structural change in the dentin, thereby altering its solubility and permeability characteristics, and helping in RCT procedure. ${ }^{17}$ Hence, we estimated the effect of root fracture strength of different irrigating solutions. Our results showed that the group containing normal saline had the highest fracture resistance compared with other groups. Among all other study groups, the group containing 10\% EDTA had the maximum fracture resistance strength $(n=540.08)$, whereas the group

Table 2: Fracture strength in all the groups

\begin{tabular}{llll}
\hline & $\begin{array}{l}\text { Maximum } \\
\text { compressive } \\
\text { load }(\mathrm{N})\end{array}$ & $\begin{array}{l}\text { Maximum } \\
\text { compressive } \\
\text { strain (\%) }\end{array}$ & $\begin{array}{l}\text { Maximum } \\
\text { compressive } \\
\text { stress (MPa) }\end{array}$ \\
\hline I & 605.59 & 12.85 & 16.60 \\
II & 542.51 & 33.95 & 14.87 \\
III & 394.06 & 17.85 & 10.80 \\
IV & 324.50 & 13.50 & 8.90 \\
V & 480.95 & 13.10 & 13.18 \\
\hline
\end{tabular}




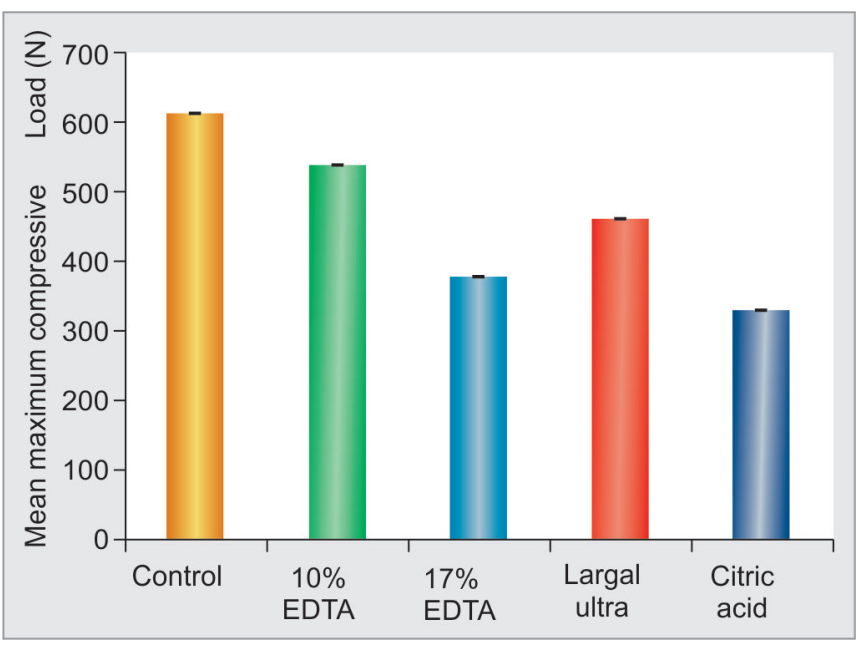

Graph 1: Comparison of maximum compressive Load $(\mathrm{N})$ of control group with four groups

containing citric acid had the minimal fracture resistance strength $(n=326.83)$ (Graph 1). Cruz-Filho et $\mathrm{al}^{18}$ also reported that EDTA solutions at varying concentrations significantly reduce the dentin hardness compared with distilled water.

In a research carried by Zehnder et al, ${ }^{19}$ results showed that citric acid has a lower surface energy than $17 \%$ EDTA, thus explaining the cause of low bond strength on its use as a final irrigant. Apart from different irrigating solutions being used to decrease the chances of root fracture, it has also been hypothesized that different techniques of condensing the root canal filling material also affect the fracture resistance of the root portion. Based on their findings, researchers postulated that the lateral condensation technique creates stresses in the root during obturation, which can create subsequent fracture. Even though the lateral condensing technique should not directly create root fracture, sufficient amount of elasticity is present in the dentin to permit separation without complete vertical root fracture. ${ }^{20}$

In a research carried by Pawlicka ${ }^{21}$ in 1982 on the hardness of the dentin portion of the root, results showed alteration in hardness due to the effect of chelators by approximately $20 \mathrm{HV}$. No difference in the change could be found between the different varieties of chelators used. Shaktidar et $\mathrm{al}^{22}$ compared the root reinforcing abilities of resilon/epiphany in endodontically treated teeth irrigated with different solutions in vitro and found that the teeth irrigated with $17 \%$ EDTA and $5.25 \% \mathrm{NaOCl}$ followed by $17 \%$ EDTA showed significantly greater resistance to fracture than the groups irrigated with $5.25 \% \mathrm{NaOCl}$ and $2 \%$ chlorhexidine. For complete cleaning of the root canal system, the irrigating solution that can dissolve both the organic component and the inorganic material is required. In addition, $\mathrm{NaOCl}$ is active only against the organic part; addition of EDTA can effectively dissolve the inorganic material, including the complete removal of the smear layer. Arslan et $\mathrm{al}^{23}$ while evaluating the effect of citric acid irrigation on root fracture in different concentrations found that citric acid used in 50\% conc. showed the highest fracture resistance compared with its various concentrations. Therefore, the type of irrigating solution does affect the root fracture resistance and the outcome of RCT procedure.

\section{CONCLUSION}

From this study, it can be concluded that among the irrigants tested, 10\% EDTA provided the highest fracture resistance compared with other irrigants as well as EDTA in other concentrations. Therefore, irrigating solution must be used during biomechanical preparation of root canal to reduce the chances of root fracture. Further research with higher and different study groups is required to search for more efficient irrigating solution to improve the outcome of RCT.

\section{REFERENCES}

1. Nair PNR, Henry S, Cano V, Vera J. Microbial status of apical root canal system of human mandibular first molars with primary apical periodontitis after "one-visit" endodontic treatment. Oral Surg Oral Med Oral Pathol Oral Radiol Endod 2005 Feb;99(2):231-252.

2. Naenni N, Thoma K, Zehnder M. Soft tissue dissolution capacity of currently used and potential endodontic irrigants. J Endod 2004 Nov;30(11):785-787.

3. Gatot A, Arbelle J, Leiberman A, Yanai-Inbar I. Effects of sodium hypochlorite on soft tissues after its inadvertent injection beyond the root apex. J Endod 1991 Nov;17(11):573-574.

4. Zehnder M. Root canal irrigants. J Endod 2006 May;32(5): 389-398.

5. Salama FS, Abdelmegid FY. Six percent citric acid better than hydrogen peroxide in removing smear layer: an in vitro pilot study. Pediatr Dent 1994 Nov-Dec;16(6):424-426.

6. Di Lenarda R, Cadenaro M, Sbaizero O. Effectiveness of 1 mol L-1 citric acid and 15\% EDTA irrigation on smear layer removal. Int Endod J 2000 Jan;33(1):46-52.

7. Meryon SD, Tobias RS, Jakeman KJ. Smear removal agents: a quantitative study in vivo and in vitro. J Prosthet Dent 1987 Feb;57(2):174-179.

8. Haznedaroğlu F, Ersev H. Tetracycline $\mathrm{HCl}$ solution as a root canal irrigant. J Endod 2001 Dec;27(12):738-740.

9. Machado-Silveiro LF, Gonzalez-Lopez S, Gonzalez-Rodriguez MP. Decalcification of root canal dentin by citric acid, EDTA and sodium citrate. Int Endod J 2004 Jun;37(6):365-369.

10. Haznedaroğlu F. Efficacy of various concentrations of citric acid at different $\mathrm{pH}$ values for smear layer removal. Oral Surg Oral Med Oral Pathol Oral Radiol Endod 2003 Sep;96(3):340-344.

11. Lam PP, Palamara JE, Messer HH. Fracture strength of tooth roots following canal preparation by hand and rotary instrumentation. J Endod 2005 Jul;31(7):529-532.

12. Holcomb JQ, Pitts DL, Nicholls JI. Further investigation of spreader loads required to cause vertical root fracture during lateral condensation. J Endod 1987 Jun;13(6):277-284. 
13. Violich DR, Chandler NP. The smear layer in endodontics: a review. Int Endod J 2010 Jan;43(1):2-15.

14. Teixeira FB, Teixeira EC, Thompson JY, Trope M. Fracture resistance of roots endodontically treated with a new resin filling material. J Am Dent Assoc 2004 May;135(5):646-652.

15. Ghorbanzadeh S, Loodaricheh SA, Samizade S, Zadsirjan S. Irrigants in endodontic treatment. Int J Contemp Dent Med Rev 2015;Article ID:030515:1-7.

16. De Assis DF, Prado Md, Simao RA. Evaluation of the interaction between endodontic sealers and dentin treated with different irrigant solutions. J Endod 2011 Nov;37(11):1550-1552.

17. Dogan H, Oalt S. Effects of chelating agents and sodium hypochlorite on mineral content of root dentin. J Endod 2001 Sep;27(9):578-580.

18. Cruz-Filho AM, Sousa-Neto MD, Saquy PC, Pécora JD. Evaluation of the effect of EDTAC, CDTA, and EGTA on radicular dentin microhardness. J Endod 2001 Mar;27(3):183-184.
19. Zehnder $M$, Schicht $O$, Sener B, Schmidlin P. Reducing surface tension in endodontic chelator solutions has no effect on their ability to remove calcium from instrumented root canals. J Endod 2005 Aug;31(8):590-592.

20. Harvey TE, White JT, Leeb IJ. Lateral condensation stress in root canals. J Endod 1981 Apr;7(4):151-155.

21. Pawlicka $H$. The use of chelating agents for widening of the root canals. Determination of microhardness. Stomatol DDR 1982 May;32(5):355-361.

22. Shaktidar PR, Kumar KN, Keerti A, Uday NM. Evaluation of influence of endodontic irrigants on fracture resistance of endodontically treated teeth obturated with resilon epiphany. J Dent Med Sci 2014 Apr;13(4):98-100.

23. Arslan H, Barutcigil C, Karatas E, Topcuoglu HS, Yeter KY, Ersoy I, Ayranc1 LB. Effect of citric acid irrigation on the fracture resistance of endodontically treated roots. Eur J Dent 2014 Jan;8(1):74-78. 